\title{
Development of the methodological approach to the comprehensive assessment of the innovative project effectiveness
}

\author{
Elena Vasilyeva ${ }^{1,2, *}$, and Yuri Krupnov ${ }^{3,4}$ \\ ${ }^{1}$ Moscow State University of Civil Engineering, 26, Yaroslavskoye sh., 129337, Moscow, Russia \\ ${ }^{2}$ Peter the Great St. Petersburg Polytechnic University, 29, Polytechnicheskaya str., 195251, St. \\ Petersburg, Russia \\ ${ }^{3}$ Moscow Region State University, 24, Very Voloshinoi str., Mytishchi, 141014, Moscow Region, \\ Russia \\ ${ }^{4}$ Financial University under the Government of the Russian Federation, 49, Leningradsky prospect, \\ 125993, Moscow, Russia
}

\begin{abstract}
Industries are able to have the considerable impact on the environment. In this regard in modern conditions, when environmental friendliness is so relevant, the considerable attention is paid to the innovative development of the industrial enterprises. But investments into innovations in turn demand the careful analysis of the innovative projects. According to the authors, the methods, widespread in practice of the investment projects assessment can be used for the assessment of innovative projects in industries, but they need some adaptation. Besides, the majority of techniques of assessment consider only separate criteria of the selection of projects for realization. But the specifics of innovative projects demand another approach; they demand a complex research of appeal of the innovative project, including not only financial performance, but also technical quality, environmental safety, economic and budgetary effectiveness, social effect, risk analysis and also the analysis of reliability and appeal of the enterprise, initiating the project. Thus, the purpose of this article was to present the algorithm of the complex analysis of the innovative project. The received results and the made recommendations can be used by potential investors as a technique of assessment of the investment attractiveness of the innovation projects in the industry.
\end{abstract}

\section{Introduction}

Nowadays investments into innovative projects determine the extent of the economy's development, and as the consequence cause the success of structures at different levels. In this regard the responsibility for making competent managerial decisions on the effectiveness assessment and on selection of innovative projects on the basis of relevant methodical provisions and criteria for projects evaluation increases.

\footnotetext{
${ }^{*}$ Corresponding author: elena.chibisova_metr@mail.ru
} 
The increasing attention has been recently given in the Russian scientific literature to the questions of the research of the innovative project effectiveness. The increasing interest of the Russian scientific community is supported with the state initiatives of formation and development of innovative programmes of the development of the Russian industry branches. The need of preliminary estimation of innovative projects is caused by the essential amount of funds, invested in innovations, the long-term nature of the projects, impossibility of the alternate capital use during the implementation of the project, relevance of competition, variety of the project results and consequences. It is also necessary to consider the deficiency of financial resources for the innovative project implementation, so that it is necessary to select only the most perspective projects and to carry out them first of all.

Theoretical bases of management of innovative projects and their effectiveness are analysed and reflected in works of many domestic and foreign scientists: Khachaturova T. C.[1], Brigkhema Yu., Erkhardta M., Berens V., Havraneka of the Item [2], Volkova A.Yu., Birmana G., Schmidt S., Biryukova A.N., Asaul M.A., Livshits V.N., Vorontsovsky A.V., Ostroukhova V. A., Makarova V.I., Kostin A. V. Antonets V.L., Kutsenko E.A., Kuvshinov M.S., Komarova N.S., Kolesnikov A.M., Rodionov D.G., Kudryavtseva T.Yu. [3], Dzhamay E.V., Kovalenko Ya.V., Kvasyuk A.V., Bessarabova A.M., Gracheva M.V., Lyapina C.B., Burmistrova I.K., Kublin I.M., Verzilina D.N., Kulakova A.O., Crow Slivinsky L.G., Elokhova I.V., Malinina S. E., Kiselyova V. A., Begashev D.A., Kozlovskaya E.A., Radionova Yu.V., Kulikovskaya N.A., Lenchuka E.B., Vlaskin G.A., Malenkov Yu.A., Malinin S. E., Maslennokova N.P., Popov A.V., Plotnikov A.N. and Plotnikov D.A., Fedosova R.N., Shalaev I.A., Akhmetshin, E.M., Bogdanova T.S., Medvedeva O.A.

However, most of authors do not consider the difference between innovative projects and investment projects. Therefore, there is the need for new approaches of the innovative project effectiveness assessment for various spheres and branches of economy.

\section{Materials and Methods}

The research was carried out with the use of systems approach, the quantitative methods, the method of scientific synthesis and also statistical and comparative analysis.

Within the research the authors studied and systematized:

- the standard technique of assessment of cost efficiency of investments developed in the USSR under the scientific guide of the well-known academician T.S. Khachaturov [1];

- the technique of the analysis of financial effectiveness of investments, developed by Industrial Development Organization of the UN (UNIDO) in 1979 [3]

- the technique of the assessment of solvency of the enterprise, which acts as the recipient of funds for the implementation of an innovative project; this technique, is used in the bank activity and often substitutes the investment analysis [5].

The offered technique was approved by one of the authors on the example of the innovative project in chemical industry and successfully applied to the assessment and confirmation of the expediency of a real project of "Pigment" public joint stock company $[6,7]$.

\section{Results}

Thus, any innovative project has both the general features of the investment project, such as systemacity, target orientation, the need of business activity, existence of a particular time frame, limited budget, cost (monetary) assessment of the project attractiveness, and the 
features of the innovative products development, including scientific and technical novelty, combination of the existing knowledge, new theoretical knowledge and results of experiments; practical feasibility, ability to satisfy particular inquiries of consumers effectiveness, the expected cost reduction as a result of the project, variety of scenarios of implementation of the project, a high risk and indeterminacies

The specified features of the innovative project determine the features of the analysis of its appeal. Considering the innovative project specifics, it is possible to offer the comprehensive approach to assessment of its attractiveness, which includes:

- analysis of reliability and attractiveness of the enterprise, acting as the initiator;

- analysis of the effectiveness of the innovative project, implemented by the enterprise.

Each of two blocks of the analysis supposes studying of a wide range of matters (Figure 1).

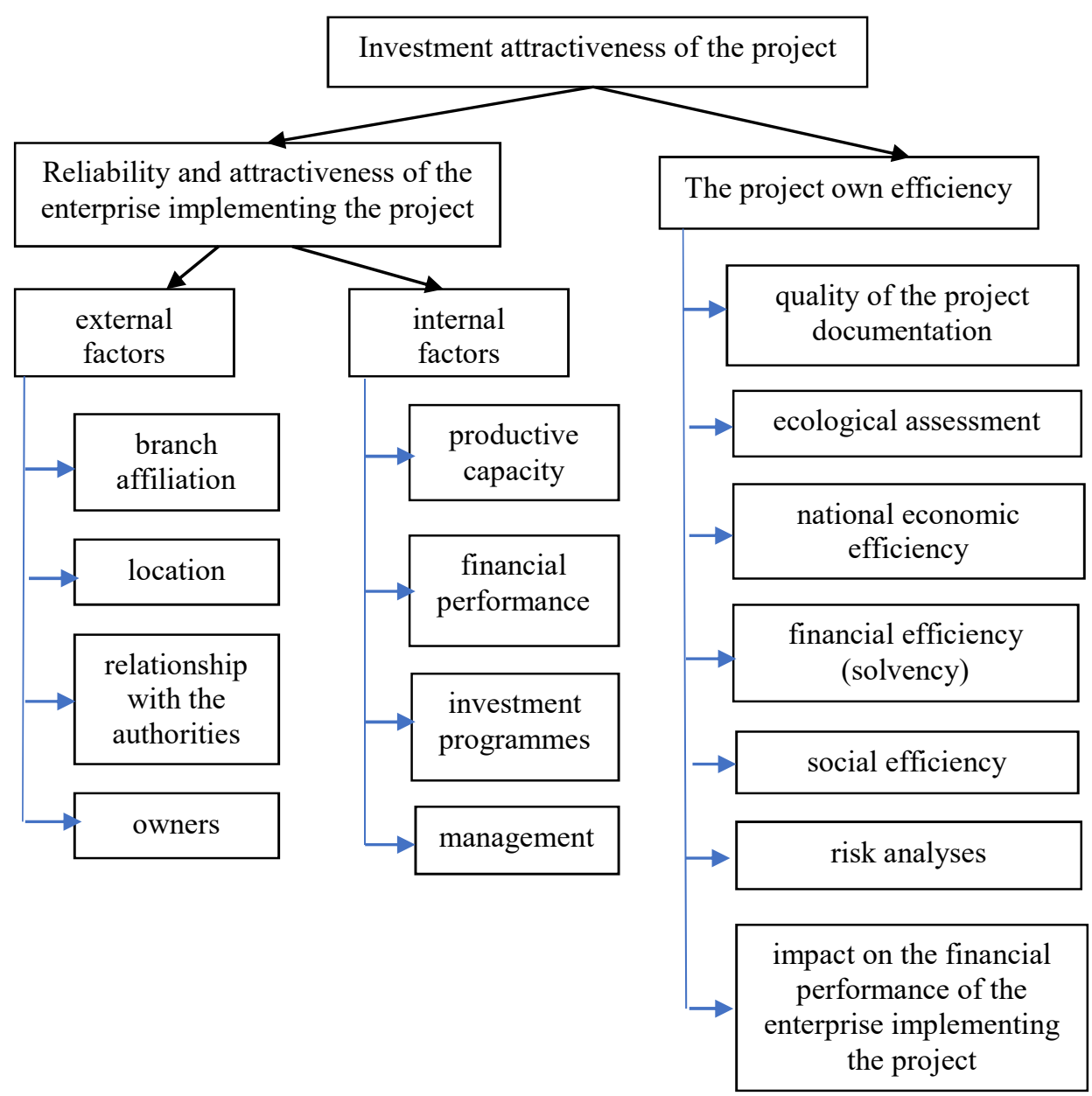

Fig. 1. Contents of the analysis of the innovative project attractiveness.

\subsection{The analysis of attractiveness of the enterprise, initiating the project}

Implementation of the innovative project happens on the basis of a certain enterprise. It can be created within the considered project; then the analysis of the enterprise attractiveness is rather brief. If the innovative project is carried out on the basis of an existing enterprise, the 
analysis of this subject represents a significant analytical work. The contents of the analysis of the attractiveness of the enterprise initiating the project are presented in Table 1.

Table 1. Elements and content of the enterprise-initiator attractiveness.

\begin{tabular}{|c|c|}
\hline Element & Content \\
\hline Branch affiliation & $\begin{array}{l}\text { Affiliation of the enterprise to a modern, perspective, } \\
\text { steadily developing industry, which products are } \\
\text { competitive at the internal and external markets, } \\
\text { prerequisites of the industry development in the next years } \\
\text { (cheap labour, possibility of inflow of cheap labour from } \\
\text { abroad, presence of highly qualified personnel, availability } \\
\text { of natural resources) }\end{array}$ \\
\hline Location & $\begin{array}{l}\text { Proximity to the sources of resources, transport paths, sales } \\
\text { markets }[8]\end{array}$ \\
\hline $\begin{array}{l}\text { Relationship with the } \\
\text { authorities }\end{array}$ & $\begin{array}{l}\text { The analysis of what relations have developed among the } \\
\text { enterprise and federal and local authorities, whether the } \\
\text { project would get approval, support, any help or face } \\
\text { obstacles. Research proved that there is a dependence } \\
\text { between the level of profitability of the enterprise and its } \\
\text { state support [9] }\end{array}$ \\
\hline Owners & $\begin{array}{l}\text { The analysis of how the property right and business } \\
\text { management are split (power and responsibility of each of } \\
\text { owners, efficiency of the business communication among } \\
\text { them), reputation of the owners and their professional } \\
\text { experience. }\end{array}$ \\
\hline Productive capacity & $\begin{array}{l}\text { The ability of the enterprise to design the innovative } \\
\text { products, to implement the innovative project, to cope with } \\
\text { financing of additional expenses }\end{array}$ \\
\hline $\begin{array}{l}\text { Financial performance of the } \\
\text { enterprise }\end{array}$ & $\begin{array}{l}\text { Financial analysis of what the investor will possess after } \\
\text { implementation of the project on the basis of the } \\
\text { aggregated balance sheet of the enterprise. }\end{array}$ \\
\hline Investment programme & $\begin{array}{l}\text { The generalizing indexes of the financial performance } \\
\text { assessment characterize its liquidity; financial stability; } \\
\text { turnover of the capital (business activity); profitability. }\end{array}$ \\
\hline Management & $\begin{array}{l}\text { The idea of the expenses, which have been already made by } \\
\text { the enterprise and of the "reserve of forces" which is } \\
\text { available still, information on the cash flows, expected } \\
\text { from other projects, experience, progress and mistakes of } \\
\text { the enterprise in the implementation of similar projects and } \\
\text { also the idea of the risk level for the investment activities } \\
\text { of the enterprise [10] }\end{array}$ \\
\hline
\end{tabular}

\subsection{Analysis of the innovative project own effectiveness}

In order to be considered efficient, any innovative project has to pass several analysis stages specified in Figure 1. Each stage supposes to study concrete characteristic of the project. Stages and contents of such analysis are presented in Table 2.

Table 2. Stages and contents of such analysis.

\begin{tabular}{|c|l|}
\hline Stage & \multicolumn{1}{c|}{ Content of the analysis } \\
\hline $\begin{array}{c}\text { Quality of the project and } \\
\text { project documentation }\end{array}$ & $\begin{array}{l}\text { Quality of the project documentation, as well as the level of } \\
\text { carrying out all the works, research, experiments necessary for the } \\
\text { goal achievement. The major questions at this stage are the } \\
\text { following: whether the projected innovative products or } \\
\text { technologies are really innovative; whether the project complies }\end{array}$ \\
\hline
\end{tabular}




\begin{tabular}{|c|l|}
\hline Ecological assessment & with the technical requirements on quality? \\
\hline $\begin{array}{c}\text { Financial efficiency of the } \\
\text { project }\end{array}$ & $\begin{array}{l}\text { Comparison of the benefits and economy in the aspect of } \\
\text { influence of the industry, enterprises, products on the environment } \\
\text { and the expenses on the compensation of the environmental } \\
\text { damage, the missed benefit, cost of nature protection measures }\end{array}$ \\
$\begin{array}{c}\text { Indexes of net present value (NPV), internal rate of return (IRR), } \\
\text { profitability index (PI), discounted payback period (DPP) (the } \\
\text { discounted methods) and the static methods: simple rate of return } \\
\text { and simple payback period. }\end{array}$ \\
$\begin{array}{c}\text { National economic } \\
\text { efficiency of the project }\end{array}$ & $\begin{array}{l}\text { Indexes of economic cost efficiency reflect the effectiveness of } \\
\text { the project in terms of the interests of the national economy as } \\
\text { whole, industries, regions. } \\
\text { General principle is the following: } \\
\text { Efficiency = }\end{array}$ \\
\hline $\begin{array}{c}\text { Impffect (the increase in profit, output, etc) } \\
\text { performance of the }\end{array}$ \\
enterprise implementing \\
the project & $\begin{array}{l}\text { Adoption of the innovative project will demand additional } \\
\text { immobilization of liquid financial resources of the enterprise, that } \\
\text { reduces the level of the current liquidity [13]. Besides, the project } \\
\text { affects the financial results of the enterprise work. }\end{array}$ \\
\hline Social efficiency & $\begin{array}{l}\text { Identification of the results (consequences) of the innovative } \\
\text { project on the conditions of the population life. The quantitative } \\
\text { assessment of social effect of the innovative project (if possible) }\end{array}$ \\
\hline Project risk analysis & $\begin{array}{l}\text { Identification of risks, bound to the project, qualitative and } \\
\text { quantitative estimation of their influence on the estimated results. } \\
\text { Development of some options of maneuvering by the project so } \\
\text { that losses in case of realization of risks would be minimized [14] }\end{array}$ \\
\hline
\end{tabular}

\section{Discussion}

As one can see, the comprehensive analysis of the innovative project can assume a rather big range of criteria and methods. However, that does not mean that all of them without exception have to be applied for the analysis of an innovative project in any conditions.

As it was offered in the previous works of one of authors [7], the choice of the used method depends on the combination "novelty of a product - novelty of the market". That is possible to be presented in the form of matrixes in Figure 2. 
- NPV, DPP

- analysis of sensitivity,

- tree of decisions
New markets

- NPV, DPP

- analysis of sensitivity, tree of decisions, bootstrap, method of "penknife", cross check, permutable testing

- expert estimates

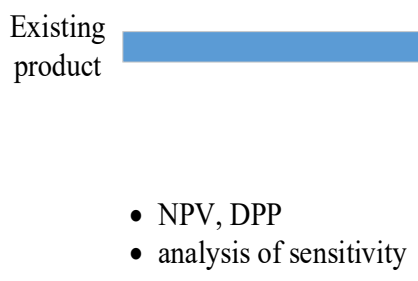

Existing markets

Fig. 2. Choice of a method of assessment in innovations.

As one can see, the more innovative is the product and the higher is the novelty of the market in which it is offered, the stronger is the role of qualitative methods of the innovative project assessment $[14,15,17]$.

\section{Conclusions}

Thus, it is possible to offer the methodical approach to the comprehensive assessment of effectiveness of the innovative project in the industry in the form of the algorithm. According to this algorithm, making managerial decision on the implementation of the project should be on the basis of the comprehensive study of characteristics of the project and also taking into account the attractiveness (solvency, etc.) of the enterprise, implementing it. The considerable attention is paid to the risk assessment, several scenarios of the innovative project implementation and the results corresponding to these scenarios are to be considered.

Application of the offered approach will allow to manage innovative projects in the industries more efficiently.

\section{References}

1. T.S. Khachaturov, Effectiveness of capital investments (Economy, Moscow, 1979)

2. V. Berens, P.M. Havranek, Guide to the assessment of investments effectiveness (Interekspert, Infra-M, Moscow, 1995)

3. D.G. Viktorovich, A.D. Andreyevna, T. Kudryavtseva, Proceedings of the 32nd International Business Information Management Association Conference, IBIMA 2018

- Vision 2020: Sustainable Economic Development and Application of Innovation Management from Regional expansion to Global Growth, 3928-3932 (2018) 
4. Industrial Investments Project Profile (IIPP) FORM, UNIDO (International Centre Austria, Venna, 1979)

5. D.A. Endovitsky, I.V. Bocharova, Analysis and assessment of the borrower's solvency (Knorus, Moscow, 2005)

6. E.Yu. Vasilieva, Fundamental and applied research in the field of management, economics and trade, 27-31

https://www.elibrary.ru/download/elibrary_39566634_30019509.pdf

7. E.Yu. Vasilieva, Russian economic online journal 3 (2019) www.erej.ru/Articles/2019/Vasilieva.pdf

8. A. Mottaeva, MATEC Web of Conferences 193, 01022 (2018) doi.org/10.1051/matecconf/201819301022

9. E. Vasilyeva, I. Polyakova, MATEC Web of Conferences 106, 08097 (2017)

10. E.M. Akhmetshin, Journal of Advanced Research in Law and Economics 8(8), 23112323 (2018) doi:10.14505/jarle.v8.8(30).01

11. E.Yu. Chibisova, Evaluating of an investment project financial efficiency (Marketing, Moscow, 2004)

12. A.V. Bataev, A.A. Gorovoy, A.B. Mottaeva, Proceedings of the 32nd International Business Information Management Association Conference, IBIMA 2018 - Vision 2020, 102-114 (2018)

13. T.Yu. Kudryavtseva, E.S. Markova, Materials of Scientific forum with the international participation, St. Petersburg, Peter the Great St. Petersburg Polytechnic University, 50-51 (2015)

14. A. Mottaeva, , E3S Web of Conferences, 110, 02166, (2019) doi.org/10.1051/e3sconf /201911002166

15. J.R. Cornwall, D.O. Vang, J.M. Hartman, Bootstrapping, Entrepreneurial Financial Management (2019) DOI: 10.4324/9780429320484-11

16. T. Sanders, Proceedings of the Edinburgh Mathematical Society (2020) DOI: $10.1017 / \mathrm{S} 0013091520000048$

17. E. Gordon, G. Mugar, Innovation (2020) DOI: 10.1093/oso/9780190870140.003.0002 